\title{
Igrici ako archaickí poeti a žreci u pohanských Slovanov. Kam ukazujú stredoveké pramene i niektoré významové dimenzie praslovanského slova ${ }^{\star}$ jьgrьcь (jeho odvodenín a kontinuantov) vo vybraných slovanských etnojazykových tradíciach ${ }^{*}$
}

\author{
Martin Golema
}

Researched are the medieval sources of pagan Slavic actors (igrci) as archaic poets and sacerdotal priests, and some dimensions of the Old Slavic word ${ }^{\star} j b g r b c b$ as followed in significant Slavic ethnolinguistic traditions.

Nebojovné muzikálne „plemeno“

Jedna z byzantských správ o Slovanoch, ktorí spolu s Avarmi v 6. storočí pustošili územia byzantskej ríše, mala zaujímavý osud. Stala sa hlavným a jediným, ako tvrdí Niederle (1953, s. 454), dôkazom nebojovnosti Slovanov, dôkazom ich „holubičej“ povahy. Slovenská a česká obrodenecká konštrukcia o „holubičej“ povahe pracovala s metaforou, požičanou ešte od českého barokového učenca J. A. Komenského a jeho termín „národ holubičí “ urobila jedným z centrálnych prvkov národného sebaobrazu v 19. storočí. V takomto duchu predstavoval starých Slovanov Herder, Šafárik i Kollár, ich predstavy podrobil zásadnej kritike J. M. Sobiestianskij v r. 1892 (Niederle, 1953, s. 451). Pre neho Slovania neboli žiadnym tichým holubičím národom, ale národom s povahou rovnako bojovnou a rovnako krutou ako ich susedia. K tomuto názoru sa prikláňal i známy český slavista L. Niederle.

Spomínanú byzantskú správu historika Theofylakta Simokattu uvádzame v slovenskom preklade v plnom znení. Išlo o troch Slovanov, ktorých chytilo v r. 591 vojsko cisára Mauríkia: „... V nasledujúci deň boli traja ludia slovienskeho pôvodu, nemajúci pri sebe žiadne meče a iné bojové zbrane, zajatí vojenskými hliadkami (Romajov). Niesli len gitary a okrem nich nemali pri sebe ničoho. Cisár sa ich vypytoval, $z$ akého sú plemena, kde majú svoje sídla a čo je príčinou toho, že prišli na romajské územie. Oni zas povedali, že pochádzajú $z$ kmeňa Slovienov, bývajú v priestore pri brehoch Západného oceánu (Atlantický oceán s Baltickým morom ako zátokou) a že kagan (avarský hlavný náčelník) až tam poslal poslov zhromažd’ovat' ozbrojené sily a náčelníkom jednotlivých kmeňov venoval velké dary. Oni síce dary vzali, ale vojenské spojenectvo mu odopreli, tvrdiac, že ich od prechodu odrádza vzdialenost'. A ku kaganovi ich teraz ako zajatcov poslali s vysvetlením, že im samým táto

Štúdia je výsledkom riešenia projektu VEGA č. 1/0583/08 - Predhistória literatúry u Slovanov (pokus o archeológiu literárnej komunikácie s akcentom na duchovnú kultúru stredoeurópskych Slovanov) 
cesta trvala pätnást' mesiacov. No kagan, nedbajúc na práva, ktoré patria poslom, rozhodol sa nepovolit im návrat. Oni však počuli o romajskom národe, že je vraj nesmierne slávny svojimi bohatstvami a žičlivostou voči každému človeku. Využili teda vhodnú chvílu a prebehli do Trákie. Nosia vraj gitary preto, že nie sú zvyknutí odievat vojenskú výstroj, lebo ich zem nepozná zbrane, čo im dovoluje žit bez vášní a v pokoji. Hrajú na lýrach, pretože nepoznajú bojové surmity. Lebo tým, čo o vojne nikdy nepočuli, je milšie zaoberat’ sa hudbou. Cisár s velkým záujmom počúval rozprávanie o tomto plemene, láskavo pohostil prišelcov z barbarskej krajiny a obdivujúc ich vzrast a skvelé postavy, vypravil ich do Herakleje..." (Pramene $\mathrm{k}$ dejinám Vel'kej Moravy, 1964, s. 52).

Táto správa, zaznamenaná pôvodne ako nie príliš dôležitá osviežujúca kuriozita, bola v 19. storočí s nadšením čítaná a interpretovaná ako zásadný dôkaz slovanskej mierumilovnosti. Takéto čítanie ignorovalo, okrem všetkých ostatných správ ukazujúcich slovanskú bojovnost', aj logický rozpor, ktorý tento „zriedený popis“ vzdelaného byzantského historika obsahuje. Spomínaný kmeň neodoprel kaganovi spojenectvo, pretože zásadne odmietal vojnu, ale preto, že ich (Slovanov) od výpravy „odrádzala vzdialenost “. Ďalšie tvrdenia Slovanov o tom, že nie sú zvyknutí odievat zbroj a že iba hrajú na lýrach, možno potom interpretovat’ aj tak, že vo vnútri kmeňa patria k skupine, ktorá je oslobodená od vojenskej povinnosti (podobne ako boli od vojenských povinností u Keltov oslobodení druidi), pretože sa špecializuje na niečo iné, najpravdepodobnejšie na poetické sformovanie a uchovanie kultúrnej pamäti.

Na rozdiel od Niederleho (1953, s. 445), podla ktorého išlo o zrejmú výhovorku troch zajatých slovanských vyzvedačov, sa domnievame, že sa vtedy antický svet stretol skôr s príslušníkmi osobitného „stavu“ vo vnútri slovanskej spoločnosti, ktorý sa mohol podobat keltským druidom alebo írskym "fili“ - básnikom a ktorého niektoré atribúty či kompetencie mohli uchovávat’ ešte stredovekí igrici, doložení v Uhorsku, či ruskí skomorochovia, ktorým vd’acíme za uchovanie archaických epických „bylín“.

Obdobné inštitúcie špecializujúce sa na uchovávanie kultúrnej pamäti predstavujú kultúrnu univerzáliu, $u$ viacerých indoeurópskych národov ešte detailnejšie určenú trojfunkčnou ideológiou; tá im udeluje presné kompetencie i základný rámec ich pôsobenia - teda výkon prvej funkcie magickej i právnej náboženskej suverenity.

Podla V. N. Toporova (Mify narodov mira 2, 1988, s. 327-328) predstavuje archaický poet, spevák (ako kultúrna univerzália) v mýtopoetickej tradícii personifikovaný obraz nadprirodzeného poznania, zbožštenej pamäti kolektívu. Dokáže všetko nazvat' svojím menom, vytvára svet $\mathrm{v}$ jeho poetickom i textovom stelesnení, paralelný s mimotextovým svetom, stvoreným demiurgom. Tvorba, vytváranie spája archaického poeta so žrecom. Poet i žrec rekonštruujú svet, rozčleňujú, rozdelujú prvopočiatočnú jednotu, ustanovujú povahu rozdelených častí cez určenie stotožnení, syntetizujú novú jednotu. Bojujú s chaosom, upevňujú organizovanost' vesmíru, jeho zákon. Opakovane robia to, čo v minulosti vykonal demiurg (kultúrny hrdina), premáhajú rozkladné tendencie, vyháňajú či spracúvajú prvky chaosu, svet sa vd’aka nim znovu a znovu „kozmizuje“, zabezpečuje sa rozkvet, bohatstvo, pokračovanie $\mathrm{v}$ potomstve. Totožnost’ archaického poeta a žreca prináša so sebou predstavu o jeho magickej sile.

Archaický poet pozná minulé, prítomné i budúce. Poznanie minulosti ho spája $\mathrm{s}$ „podsvetím“, so svetom mŕtvych. Je prostredníkom nielen medzi minulostou a budúcnostou, ale aj medzi „druhým“ svetom a týmto svetom, to ho zbližuje so šamanom. Toporov upozorňuje, že táto súvislost’ je evidentná napr. v keltskom pomenovaní básnika - fili, kto- 
ré je odvodeninou zo starého indoeurópskeho koreňa *uel-, označujúceho súčasne smrt', královstvo mŕtvych, bohatstvo, moc. Z toho istého koreňa je odvodené slovanské teonymum Veles a v Slove o pluku Igorovom, staroruskej pamiatke, sa čarodejný poet Bojan označuje ako „vnuk Velesa“. Dvojitej prirodzenosti archaického básnika ako sprostredkovatela medzi dvoma svetmi zodpovedá existencia osobitného jazyka (napr. indoeurópsky poetický jazyk, „jazyk bohov“ v gréckej, iránskej, škandinávskej, chetitskej tradícii).

Ak máme uvedené zistenia V. N. Toporova zhrnút, archaický poet prostredníctvom mýtu ako univerzálneho výkladu sveta vychádzal v ústrety jednej z najintenzívnejších ludských potrieb - potrebe „vyznat’ sa v prostredi, ukladat do neho pravidelnosti a štruktúru, likvidovat kognitívny chaos “ (Kováč, 1994, s. 7). Na výkon tejto funkcie musel byt archaický poet-spevák charizmaticky kvalifikovaný, musel sa odlišovat od „obyčajného“ človeka, od „laika“. Tento rozdiel opisuje Assmann (2001, s. 50) aj ako polaritu medzi „všednou“, komunikatívnou pamätou bežných ludí a „sviatočnou“ kultúrnou pamätou, v rámci ktorej sa skutočná história mení na históriu spomínanú, teda na mýtus. Kultúrna pamät má vždy svojich špeciálnych nositelov. „Patria k nim šamani, bardi, grioti práve tak ako kňazi, učitelia, umelci, spisovatelia, učenci, mandaríni, či inak nazývaní splnomocnenci poznania. Nekaždodennosti zmyslu, ktorý sa v kultúrnej pamäti udržuje, zodpovedá určitá povznesenost' nad všedný deň a oslobodenie od každodenných povinností u jej špecializovaných nositelov" (Assmann, 2001, s. 51).

Assmann považuje za preukázané, že poetické sformovanie obsahov kultúrnej pamäti má predovšetkým mnemotechnický účel, spočívajúci v tom, že „dovedie poznanie, ktoré zaistuje identitu, do udržatelnej podoby“ (s. 54). Orálne tradovaná poézia, ktorá kvôli tomuto cielu vzniká, nie je jednoducho jednou z foriem reči vedla iných, v archaických (predpísomných) kultúrach má vel’mi často privilegovaný nárok na pravdu, pretože „,... čerpá $z$ vešteckej moci, božského vnuknutia a svetskej múdrosti, je ako ústredná inštancia kultúrneho poznania nositelom praktických skúseností a znalostí, kolektívnou pamätou, kozmogóniou a kultovou praxou súčasne" (Struck, 1999, s. 186). Poeticky sformované obsahy kultúrnej pamäti sa potom počas sviatočných zhromaždení opakovane predvádzajú v podobe „multimediálnej inscenácie, ktorá jazykový text neodlučitelne začleňuje do hlasu, tela, mimiky, gestiky, tanca, rytmu a rituálneho konania“ (Assmann, 2001, s. 54). Takáto opakovane oživovaná kultúrna pamät tvorí „konzervatívnu protiváhu voči náhodnosti a pretržitosti krátkodobých politických a ekonomických procesov, rituály, symboly, mená sú pritom nielen znaky historicky získaných skúseností, ktoré sú v nich akoby akumulované, ale svojou systematickou súvislostou štrukturujú tiež preživanie prítomnosti“ (Struck, 1999, s. 197).

Práve sviatky a zhromaždenia (napr. obrady, hostiny) sú vonkajšími podnetmi, v rámci ktorých sa táto poeticky sformovaná kultúrna pamät', akumulovaná v živej pamäti špecialistov, periodicky oživuje. Sú skutočne príležitostou, počas ktorej kraluje spomienka ako „najvyššia vládkyňa kultúry“ (Curtius, 1998, s. 425). Predstavujú „nápravu všedného dňa“ (Aasmann, 2001, s. 54), účast’ na iniciáciách otcov, ktorá dodáva silu „k novým začiatkom a novému usilovaniu“ (Curtius, 1998, s. 425). Práve v rámci týchto zhromaždení sa všedná hierarchizovaná štruktúra spoločnosti dočasne rozpúšta, mení sa na to, čo predstavitel' symbolickej antropológie Viktor Turner (2004) nazval antištruktúra alebo communitas. Tá je podla neho antropologicky univerzálna a vzniká predovšetkým v rámci iniciačných, prechodových rituálov. V ich rámci sú ludia dočasne „uvolnení zo štruktúry do communitas“, aby sa spät’ do štruktúry vrátili obrodení zážitkom mysticky zjednotenej 
communitas, ktorá je „skoro všade pokladaná za svätúu (Turner, 2004, s. 124), teda sviatočnú. Podla Turnera je isté, že žiadna spoločnost’ nemôže bez tejto dialektiky normálne fungovat', ludské konanie iba v rámci všednej, každodennej a profánnej štruktúry sa totiž „rýchlo stáva suchopárnym a mechanickým, pokial'sa tí, ktorí sú v ňom zapojení, pravidelne neponárajú do regenerujúcej hlbočiny communitas" (Turner, 2004, s. 136).

Hlavnou postavou takýchto „nápravných“, iniciačných sviatočných zhromaždení (communitas, ak použijeme výstižný Turnerov termín) býval archaický poet a žrec $\mathrm{v}$ jednej osobe. Nazdávame sa, že traja neozbrojení Slovania s gitarami, ktorých v r. 591 byzantskí vojaci priviedli k cisárovi Mauríkiovi, neboli exemplárnymi predstavitel’mi akéhosi muzikálneho „holubičieho národa“, principiálne odmietajúceho vojnu, neboli to ani dobre maskovaní vyzvedači (to by určite skúsený vojenský velitel’ zistil a neprepustil by ich). Najpravdepodobnejšie to teda boli slovanskí archaickí poeti a žreci, ktorí cisárovi presvedčivo predviedli svoje umenie.

\section{Indoeurópski tvorcovia formúl a znalci slov}

Archaickej trojfunkčnej indoeurópskej ideológii azda najlepšie zodpovedá sociálna štruktúra starovekej Indie. Indická „védska“ spoločnost’ sa skladala (podobne ako európska stredoveká spoločnost’, či francúzska spoločnost’ pred Velkou francúzskou revolúciou) z troch stavov: „z tvorcov formúl, znalcov slov, myslitelov, intelektuálov (pôvodný význam slova brahman bol približne účinná slovná konštrukcia, formula, modlitba), d’alej mocných bojovníkov královskej družiny (kšatra - vláda, panstvo, rádža - král) a z dedinčanov, hospodárskych tried - pastierov, pestovatelov, remeselníkov (viš - kmeňová dedina, véša - dom, domácnost')“ (Puhvel, 1997, s. 62); dodajme, že z tohto starého koreňa pochádza i slovanské ves - dedina. Táto sociálna štruktúra predstavovala iba jednu z možných aplikácií trojfunkčnosti, rôzne pôvodne indoeurópske kultúry sa od nej niekedy radikálne vzdialili (napr. starovekí Rimania), napriek tomu uchovali dôležité stopy trojfunkčnosti v iných sférach života - napr. v národnom epose.

Otázka existencie kňazských zborov u pohanských Slovanov, porovnatelných s indickými brahmanmi či keltskými druidmi, je zložitejšia. Zlomkovito zachovaný textový materiál, v ktorom dominujú „zriedené opisy“ vonkajších pozorovatelov, dovoluje viacero interpretácií. Vel’mi skepticky sa k existencii vyčlenených špecialistov na prvú funkciu stavia Z. Váňa. Podla neho sa u Slovanov nevyvinula tripartita funkcií v Dumézilovom zmysle, ale skôr bipartita funkcií - jej projekciu v slovanskom panteóne predstavuje Perún, boh vojny s elementom suverenity a Veles, boh tretej funkcie s elementom mágie. Kňazská kasta, s ktorou by mala súvisiet’ prvá funkcia náboženskej suverenity, vznikla len u polabských Slovanov a inde chýba. Nositelmi kultu podla Váňu boli pôvodne len rodoví a kmeňoví vodcovia, prípadne „čarodejníci“, ktorí hrali určitú spoločenskú rolu hlavne na východe (Váňa, 1990, s. 263).

Tento názor sa pokúsime falzifikovat'. Nenazdávame sa, že tripartita u Slovanov sa „nevyvinula“, pretože predstavovala spoločné indoeurópske dedičstvo. Mohla sa však menej výrazne či inak premietat’ do reálneho členenia spoločnosti. Niečo analogické konštatuje Dumézil u Skýtov: „Predovšetkým sa nezdá, že by u Skýtov bola ,trieda kňazov. Hérodotos uvádza z odborníkov len čarodejníkov - veštcov... a ak odhliadneme od veštenia, potom náboženské úkony vykonávali náčelníci, začínajúc králmi až po hlavy rodín. V tom sa Skýti zretelne lísili od svojich bratrancov v Iráne a zhodovali sa s Indoeurópanmi na východe 
a severe Európy: taká bola situácia u slovanských národov, kým sa neobrátili ku krestanstvu, a tiež u Germánov, ktorí nič porovnatelné s keltskými druidmi nepoznali“ (Dumézil, 2001, s. 472).

Neistota panuje aj v otázke, či existovala kňazská trieda u Baltov, jazykovo Slovanom najbližších Indoeurópanov. Eliade (1997, s. 35) cituje zaujímavý doklad, ktorý by mohol niečo ukazovat', ide o zmluvu, ktorú v roku 1249 vnútili rytieri teutónskeho rádu Staroprusom: „... je to prvý písaný doklad o baltskom náboženstve - zaväzovala porazených, aby prestali pálit alebo pochovávat mŕtvych spolu s koňmi alebo služobníctvom, so zbrañami, oblečením alebo d’alšími cennými predmetmi; aby prestali po žatve prinášat obete idolu Kúrche a d'alším bohom; aby sa prestali radit's vizionárskymi bardmi (tulissones alebo ligaschones), ktorí prednášajú smútočné prejavy na pohrebných hostinách a tvrdia, že vidia zosnulých, ako letia v povetrí na koni na druhý svet. Medzi vizionárskymi bardmi rozoznávame triedu extatikov a čarodejníkov podobnú ázijským šamanom. Je velmi pravdepodobné, že v závere „pohrebnej hostiny' odvádzali dušu mŕtveho na druhý svet “ (Eliade, 1997, s. 35). Iné doklady (Kronika Pruska z r. 1326) spomínajú pohanského „pápeža“ s menom Criwe a so sídlom v Romuve, ku ktorému prechovával vel'kú úctu král, šlachta i prostí ludia (Puhvel, 1997, s. 259).

Kosmova kronika spomína zase iniciatívu českého kniežata Břetislava (1002-1055), ktorý „při počátku svého knížectví, roznícen jsa velikou horlivostí pro křest’anské náboženství, vyhnal pryč ze své země všechny čaroděje, hadače a věštce..." (Kosmova Kronika česká 1975, s. 143).

Dôležitých stôp výkonu prvej funkcie je v slovanských tradíciách pomerne mnoho, po niektorých z nich sa vydáme aj v našej štúdii.

\section{Náboženská suverenita - jej nositelia a ich oponenti}

Trojfunkčná indoeurópska ideológia v tej podobe, v akej ju rekonštruoval Dumézil, upravovala zaujímavým spôsobom postavenie pamätových špecialistov v spoločnosti. Kodifikovala ich nadradenost’ nad ostatnými dvomi funkciami, túto ich špeciálnu sociálnu pozíciu nazval Dumézil náboženskou suverenitou. Napr. indickí brahmani stoja v systéme kást nad šlachtou (kšatrijmi), ku ktorým patria i vládcovia (rádžovia). Aj Platónovu predstavu o vláde filozofov nad vojakmi a výrobcami považuje Dumézil za špeciálnu verziu tejto velmi starej predstavy.

Domáhanie sa práva na výkon suverenity zo strany pamätových špecialistov je teda v rámci trojfunkčnej ideológie úplne legitímne, je ňou podporované, a preto i zvlášt časté v spoločnostiach, kde aspoň čast populácie je dedičom indoeurópskych tradícií. Ich logickým potenciálnym odporcom sú bojovníci, disponujúci „svetskou“ mocou, a ich predáci - často králi či kniežatá - zrastení skôr s touto skupinou.

Títo mocní protihráči pamätových špecialistov disponujú „silou“ (presný sémantický ekvivalent sanskrtského výrazu kšatra - sila, odvaha, výkonnost'), sú to predstavitelia vojenskej aristokracie, napr. írska šlachta - flaith (porovnatelné galské vlato), nemecké Gewalt (Dumézil, 1997, s. 74) a slovanské vláda.

Doklady konfliktu prvofunkčnej náboženskej nadradenosti a vojenskej sily i jeho paradigmatické riešenia môžeme nájst' napr. v indickom či rímskom panteóne: „... ani $v$ Indii ani v Ríme nie sú bohovia prvej funkcie, Varuna, Jupiter, bez záujmu o vojnu: pokial'sa nezapájajú, tak ako Indra a Mars priamo do bojov, dávajú svoju mágiu do služieb tej strany, 
ktorej dávajú prednost', a sú to oni, ktorí s definitívnou platnostou pririeknu vítazstvo, ktoré aj ked' je v skutočnosti dobyté silou, má svojimi dôsledkami význam predovšetkým pre poriadok" (Dumézil, 1997, s. 122).

Pekné príklady obsahujú i správy o keltských druidoch a ich dedičoch, írskych fili. Antické správy o druidoch opisujú, ako vo vojnách zavše vyšli medzi nastupujúce nepriatel'ské oddiely a hatili ich v boji. Vyzeralo to, akoby boli krotili divú zver. „Takto sa aj $u$ najhrozivejších barbarov vášeň skláňa pred múdrostou a Áres sa poddáva Múzam" (Herm, 1985, s. 65). Írski „fili“ sa zase uplatňovali ako radcovia krála, ktorý bol ako každý šlachtic závislý na ich chválospevoch alebo satirách. Pôsobili teda na privilegované vrstvy „ako určitá cenzúra a mohli tak presadzovat morálne chovanie, pravdu a štedrost" (Botheroydová - Botheroyd, 1998, s. 126). Zaklínaním, hladovkou a čarami mohli donútit krála, aby splnil svoje povinnosti (írsky sv. Patrik pokračoval v tejto tradícii a použil hladovku ako magický nátlakový prostriedok proti Bohu Otcovi osobne (!) (s. 192), štyridsat dní sedel bez jedla a nápoja na vrchole posvätnej hory Croagh Patrick, obtažovaný hroznými čiernymi démonickými vtákmi, až to už nebo nemohlo zniest’ a vyhovelo jeho prosbe, aby mohol pri poslednom súde účinkovat ako sudca Írov (s. 368)). Mnohé dalšie príklady by sa dali vybrat aj zo stredovekých bojov o investitúru.

Pre predstavitelov druhej, vojenskej funkcie malo nesmiernu hodnotu symbolické vyjadrenie ich hrdinstva, to, čo napísal o írskych fili Herm, mohlo do velkej miery platit aj napríklad pre slovanských igricov na Vel'kej Morave či v neskoršom Uhorsku až do čias, kým cirkev definitívne nepodlomila vplyv tejto svojej konkurencie s pohanskými koreňmi. Ked' írski fili „... vstali a v sprievode harfistov prednášali dávne príbehy či zvesti o žijúcich hrdinoch, ostrielaní bojovníci im priam lipli na perách, boli ako herci, ktorí sa práve dozvedajú, či obstáli, alebo nie. Až kritika z povolaných úst puncovala alebo znivočila slávu, ktorú si nárokovali. A beda šlachticovi, ktorý pevca bohato neodmenil!“ (Herm, 1985, s. 250).

Ságy, ktoré írski „fili“ prechovávali vo svojich hlavách, neslúžili iba zábave, boli považované aj za zbierku precedenčných právnych prípadov. „Ked' sa vynorila otázka, ako treba aplikovat'v tom či onom akútnom prípade daktorý zo zložitých írskych zákonov zachytených vo veršoch, právni zástupcovia - zrejme to boli ludia ovládajúci všetok písomne nezachytený materiál - hladali to, čo britskí a severoamerickí advokáti označujú za, leading case - ,orientačný prípad“ - teda (mytologickú) situáciu podobnú tej, v ktorej sa ocitol ich mandant“(s.250).

Títo zvláštni „básnici“ teda rozhodovali i súdne spory, mali teda „pod palcom“ právny pól náboženskej zvrchovanosti. Zasahovali „vinníkov“ i mágiou - napr. írsky sv. Columcille, žiak a uchovávatel tradícií týchto „fili“, si od nich osvojil schopnoste účinne preklínat zlosynov, ešte počas výučby odpravil touto cestou zo sveta jedného prznitela panien, rovnaký osud pripravil tento skutočne špecifický írsky svätec lupičom, vrahom, chamtivým králom, prenasledovatelom nevinných, lud’om neuznanlivým a nevdačným, ba dokonca aj jednému kancovi (Botheroyd - Botheroydová, 1998, s. 365). Skutočne usilovne teda dbal o dodržiavanie vesmírneho poriadku i prostredníctvom mágie a ked'bolo potrebné, neváhal ani privodit kliatbami neštastie a smrt'.

Írski fili predstavujú mimoriadne dobre zdokumentovaný prípad úsilia o zvrchovanost', miestne krestanstvo ich tradície dokázalo kultivovane a tolerantne absorbovat', čo vôbec nemožno povedat’ o zvyšku Európy, kde to mali miestni poeti - žreci, uchovávatelia lokálnych predkrestanských tradícií, ovela tažšie. Bežnou praxou bolo skôr surové vyháňanie, mučenie či fyzická likvidácia. Írsko teda predstavuje v rámci Európy „muchu 
v jantári“ (Herm, 1985), ked’ sa na ňu zahladíme, môže nám to vel’mi pomôct’ predstavit’ si staré kompetencie i slovanských pohanských pamätových špecialistov. Fili mohol vykonávat’ svoju funkciu až po dvanástročnom štúdiu, počas ktorého sa musel naučit naspamät stovky básní, príbehov, vysvetlení miestnych mien atd’. Najvyšší írsky fili - ollam (majster) mal právny nárok byt miestokrálom, musel poznat’ „všetky básne“ a byt schopný vyjadrovat’ sa za každých okolností v improvizovanej, zložitej básnickej forme. Zároveň zodpovedal za zostavenie a dalšie vedenie genealógií, zaznamenanie dejinných udalostí a za objasnenie vlastných mien, osobných i miestnych (Botheroydová - Botheroyd, 1998, s. 299). Keltskí druidi a ich neskorší írski dediči (fili) vytvárali uzavreté a dobre organizované bratstvá, $\mathrm{k}$ ich výsadám patrilo oslobodenie od daní i vojenskej povinnosti, neobmedzená vol’nost’ pohybu. Podriad’ovali svojmu vplyvu krála, vychovávali vojenskú aristokraciu. Ich „pracovným“ nástrojom bola reč, ňou ovplyvňovali chod sveta. $\mathrm{V}$ ich repertoári mali svoje miesto magické formulky, hrdinské spevy, zaklínania, zlorečenia. Ich pochvalné alebo posmešné básne „slúžili $k$ tomu, aby zmenili morálne chovanie vysoko postavených osôb, niekedy tiež aby podlomili ich zdravie. Urazený alebo rozhorčený druid mohol silou svojej reči usmrtit' toho, kto ho urazil" (Botheroydová - Botheroyd, 1998, s. 101).

Tieto bratstvá hovorili „rečou bohov“, nadprirodzených bytostí, používali starobylý poetický jazyk, ktorým sprostredkovávali vôlu bohov. Nešlo teda o akýchsi zabávačov, šašov, komediantov, loajálnych ospevovatelov svojich chlebodarcov, prispôsobujúcich sa nálade obecenstva. Neboli to ani hudobníci, vyznačujúci sa maximálnou adaptabilitou, ktorí vždy ponúkali to, čo sa od nich žiadalo.

To, čo vo vnútri predkrestanskej i polokrestanskej, trojčlennou indoeurópskou ideológiou presiaknutej kultúry bolo ich základným záväzkom, bol výkon prvej funkcie náboženskej suverenity. Inscenovali a oživovali orálne tradované obsahy kultúrnej pamäti nielen s cielom pobavit publikum, používali ich aj na niečo ovela závažnejšie, a to síce ako konzervatívnu protiváhu voči náhodnosti a pretržitosti krátkodobých politických a ekonomických procesov, používali ich na obnovenie poriadku sveta v súlade s mýtom. Uchovávali kultúrnu pamät spoločenstva, niekedy aj v konflikte so svetskou (vojenskou) mocou, nie vždy ochotnou rešpektovat’ mytologické vzory, ochotnejšie podliehajúcou dobovým módam. Tieto bratstvá boli klúčovou prvofunkčnou inštitúciou, ak teda aplikujeme na nich klasickú definíciu inštitúcie (Kanovský, 2004, s. 41), mali svoju štruktúru, personál, normy, pravidlá, hmotné zariadenie, aktivity a funkciu ako integrovaný výsledok činnosti.

Niektoré dôležité jazykové indície ukazujú na existenciu podobnej inštitúcie u Slovanov. V. V. Ivanov a V. N. Toporov ukazujú na genetickú príbuznost́ staroírskeho "fili“ - básnik, staroruského „velzti“ - hovorit osobitným spôsobom a slovanského teonyma „Veles“ (v staroruskej pamiatke Slovo o pluku Igorovom (1986) je dávny básnik Bojan označovaný ako „Velesov vnuk“, „čarodejný Bojan“, „dávny veštec Bojan“).

V spomínanom Slove o pluku Igorovom odvolávajúcom sa na dávnu poetickú tradíciu je evidentné, že autor nie je nejaký servilný „pritakávač“, ale velmi tvrdo a adresne hodnotí skutky kniežat a bojovníkov. Ponorený napoly v pohanských predstavách (v básni je množstvo mytologických narážok - vznikla okolo r. 1185 - 1188), používajúci prepracovaný básnický jazyk, podložený určite dlhou predkrestanskou tradíciou, vykonáva na skutočne vysokej úrovni funkciu náboženskej suverenity, t. j. vychováva a podrobuje svojmu vplyvu počúvajúcu kniežaciu družinu. 
Náznak podobných kompetencií uhorských igricov je evidentný aj v jednej zmienke najstaršej uhorskej tzv. Anonymovej kroniky (napísanej okolo roku 1200). Pevci - igrici mali teda ešte $\mathrm{v}$ časoch anonymného kronikára ambíciu (a zdá sa, že aj priestor) vykonávat' funkciu spomínanej náboženskej suverenity - do ich kompetencie patrilo totiž pridelenie „slávy“ a „dobrého mena“. Preklad tejto pasáže znie takto: jeden z hrdinov z obdobia príchodu Madarov do Podunajska chcel viest' vojnu, „... lebo chcel osobne získat' slávu a zem, tak ako nôtia naši pevci (ioculatores): V̌̌etci si nadobudli zem a získali dobré meno" (Kronika anonymného notára... , 2000, s. 71). Autor týchto riadkov, bezmenný notár uhorského krála Bela III., ktorý sa podujal zachytit dejiny uhorských kniežat do doby krestanského krála sv. Štefana, stál - ako sám v úvode kroniky píše - pred tromi možnostami. Mohol vychádzat $\mathrm{z}$ „nepravdivých povestí vidiečanov“, „z táravého spevu igricov" na šlachtických dvoroch a jarmokoch, alebo „z presného vysvetlenia písomností a jasného výkladu dejín“ dostupného iba duchovným. Ako vzdelaný klerik si vybral poslednú možnost', od prvých dvoch ho odrádzalo najpravdepodobnejšie silné zmytologizovanie (javilo sa mu ako snovost') epickej látky, typické pre oba „nevzdelané“ stavy. Ako píše, bolo by „náramne nedôstojné a neprimerané, keby sa (ten) tak vznešený národ mad’arský len tak, akoby vo sne, dopočul o svojom pôvode a o svojich udatných činoch a skutkoch" (Kronika anonymného notára, 2000, s. 35).

\section{Velkomoravskí a uhorskí igrici ako tvorcovia formúl a znalci slov}

Touto argumentáciou smerujeme k hypotéze, že mimocirkevní pamätoví špecialisti, na Vel'kej Morave a v stredovekom Uhorsku známi pod názvom igrici, neboli pôvodne len loajálni zabávači, ako sú charakterizovaní v odbornej literatúre (napr. Rybarič, 1984, Krzemieńska - Třeštík, 1979, s. 121), Krajčovič (2005)). Boli to skôr špecialisti na výkon prvej funkcie náboženskej suverenity, pôsobiaci v tejto sfére až do času, kým ich cirkev ako konkurenciu definitívne nevytlačila ako „iba zabávačov“ na sociálnu perifériu.

Ich staré kompetencie môžeme rekonštruovat' len nepriamo, spolahlivých a detailnejších správ z Vel'kej Moravy či zo stredovekého Uhorska je velmi málo. Pokúsime sa nájst' mladšie stredoeurópske analógie. Český kronikár Kosmas (1045-1125) sa odvoláva na staršiu epickú tradíciu týmito slovami: „A tak jsem počal své vypravování od prvních obyvatelů země české a jen něco málo, co jsem poznal z báječného podání starců, vykládám, ne z touhy po lidské chvále, nýbrž aby pověsti neupadly vưbec v zapomenutí, podle toho, jak umím a vím, lásce všech dobrých lidi" (Kosmova Kronika česká, 1975, s. 7). V súvislosti s touto pasážou kladie zásadnú otázku Karbusický (1995, s. 201): „Môže Kosmov výraz,podanie`(,relatio') znamenat' epický spevný prednes a výraz,starec'(,senex') jeho prednášatela, potulného či dvorského speváka?" Karbusický prichádza k dôležitému a dobre podloženému záveru: nešlo o spomínanie starých ludí, ale o štylizované podanie profesionálov - spevákov staršieho typu, tradičnejších ako mímovia či jokulátori (prednášajúci iba burleskné a iné zábavné látky). Jokulátor (z latinského ioculator - vtipkár, figliar) ako typ na kniežati úplne závislého hudobníka a speváka je v Čechách (i v Uhorsku) doložený až od 12. storočia. Prednášatelia mýtických látok, ako je napr. „dívčí válka“, „konzervovali staršie štádiá epiky, pre ktoré sa už v dvorskej sfére vytrácali spoločenské podmienky existencie. Prednášatelia takýchto látok neboli toho druhu, aby ich Kosmas mohol označit termínom ,jokulátori. V každom prípade to však neboli „prostí ludoví rozprávači“, ale určitá inštitúcia: títo ,starci sa síce mohli ešte uplatnit’ vo vyššom prostredí, ale boli príliš spojení so starou 
kmeňovou kultúrou. “ Napriek tomu „ešte mali prístup do vy̌̌šieho sociálneho prostredia Kosmovej doby" (Karbusický, 1995, s. 210).

Podobné postavy „starcov“ sa mihnú aj v inej časti Kosmovej kroniky. Dovolíme si predpoklad, ktorý už nemôžeme opriet’ priamo o Karbusického zistenia. Knieža Boleslav I. (asi 915-967 či 972), české knieža z rodu Přemyslovcov, vrah sv. Václava a uzurpátor kniežacej moci sa rozhodol založit si nový hrad „po zpusobu římském“, teda na rozdiel od tradičných drevených slovanských hradísk hrad murovaný. „A ihned svolal přední muže z lidu, všechny do jednoho, na jedno místo a dovedl je do lesa u řeky Labe, a označiv jim místo, vyjevil jim tajné př́ní srdce svého řka: ,Zde chci a káži, abyste mi po ř́mském způsobu vystavěli hradní zed'velmi vysokou dokola. K tomu oni odpověděli: , My, kteří jsme ústa lidu a držíme odznaky svých hodností, my ti odříkáme, protože ani neumíme ani nechceme učiniti, co nařizuješ, vždyt'ani naši otcové nic takového dř́ve nečinili. Hle, stojíme před tvýma očima a raději skláníme své šije pod tvým mečem než pod nesnesitelným jhem roboty. Učiň, co chceš; nebot' neposlechneme tvého rozkazu: Tu kniže vzplanul strašným hněvem a vyskočiv na zpuchřelý kmen, jenž tam v lese právě ležel, a vytasiv meč zvolal: ,Lenochové a líných otců synové! Nejste-li polomuži nebo tvorové, kteří nestojí ani za špinavou slupku z hrušky, dokažte skutky svá slova a zkuste, zda je lehčí skloniti šije pod mečem či pode jhem roboty." A tu nastala podívaná pamètihodná a úžas budící nad drzostí smělého knízete: kdyby byl měl tisíc pravic na jednom těle a v každé zbraň, nebyl by se tak četný zástup tř́sl o nic ménè. Kníže spatřiv, že jsou bledí jako stěna, chytil jednoho, který byl první mezi staršími, za kštici a t’av, jak mohl nejsilněji, usekl mu hlavu jako chabou makovici “ (Třeštík, 1966, s. 150).

Popisovaný odpor „predných mužov“, tradicionalistov, držiacich v rukách nekonkretizované odznaky svojich hodností (odznakom írskych fili bola palica a plášt'), môže byt interpretovaný dvojako. Nemuselo íst’ o predákov tretej funkcie (rolníkov, výrobcov), ich sebavedomie, lipnutie na tradícii, i odvolávanie sa na akési staré privilégiá - oslobodenie od podobných povinností - naznačujú čosi iné. Mohlo íst' skôr o jeden z prípadov, ked’ sa mocný vládca usiluje zasahovat pamätovým špecialistom do ich funkcie (rituály, spojené so založením hradu, magické posvätenie jeho pôdy, určenie stavebného materiálu, vykonanie obetí), snaží sa naklonit’ si ich, korumpovat alebo zlomit'. V tomto prípade sa to mohlo podarit’ a Boleslav tak proti vôli zástupcov prvej funkcie, nárokujúcej si v tejto veci suverenitu, započal éru murovaných hradov v Čechách, ktoré už nerešpektovali dávny, tradovaný a ochraňovaný mýtický prototyp a aplikovali radšej „cudzie“ rímske vzory. Prední muži označujú sami seba ako „ústa ludu“, táto metafora má dávnu indoeurópsku tradíciu a slúžila velmi často na označovanie predstavitelov prvej funkcie.

Velmi zaujímavé zistenia, indikujúce bohaté vedomosti z oblasti astronómie u dávnych Slovanov, prezentuje slovinský archeológ Pleterski (1996) vo svojich výskumoch slovanských kultových miest. Pravidelne sa vyskytujúce trojice týchto miest (vrchol hory, prameň, posvätný kameň) zvierajú priestorovo $22^{\circ}-23^{\circ}$ uhol, ktorý zodpovedá presne uhlu medzi horizontom a poludňajším slnkom v čase slnovratu. Aj tu môže byt dôležitá indícia, naznačujúca existenciu špecialistov, uchovávajúcich dlhoročné pozorovania, zodpovedných aj za členenie času, teda napr. za synchronizovanie a načasovanie ludských činností (sejba, orba, sviatky) a vegetačných cyklov.

Termín jokulátor (ktorým sú uhorskí igrici označovaní napr. v uhorskej Anonymovej kronike napísanej približne v roku 1200) nepovažujeme za ekvivalentný interpretant slova igric. Treba si uvedomit možný a pochopitelný významový posun, ktorý v rámci svojej rétoriky, igricom určite nie príliš priatel’skej, využili stredovekí klerici na označenie 
svojej pohanstvom presiaknutej konkurencie. Preklad slovanského igric latinským jokulátor sa, v rámci „zriedeného popisu“ od predstavitel’ov cirkvi nemusel riadit úprimným hladaním čo najpresnejšej ekvivalencie, ale skôr snahou dehonestovat', označkovat’ a vytesnit’ nebezpečného konkurenta, významový rozdiel môže byt' podobný ako medzi slovami spisovatel' a grafoman.

Skôr ako o absolútne ekvivalentný preklad išlo o „nekonečnú semiózu“, vel’mi presne popísanú Ch. S. Peircom. Podla Peirca znak nielen niečo zastupuje, ale zároveň sa k niekomu obracia, „t.j. v jeho mysli tvorí ekvivalentný alebo zložitejší znak. Takto vytvorený znak nazývam interpretant pôvodného znaku“(Peirce, 1998, s. 131). Interpretácia je teda proces „rodenia jedného znaku z druhého“, „výkladom znaku nie je význam, ale iný znak“ a „celkovým zámerom znaku je, že bude interpretovanýv vinom znaku“ (Buczynska - Garewicz, 2000, s. 56). Interpretáciou, teda napr. aj prekladom slova do iného jazyka vzniká jeho často neidentická kópia, replika, interpretant pre ktorý platí: „... interpretant nie je nič iné, než iná interpretácia, ktorej sa odovzdáva pochodeň pravdy“ (Buczynska - Garewicz, 2000, s. 58). Takýto výsledok interpretácie (prekladu) je iný znak alebo súbor znakov, ktorý podla Ricoeura „prekladá“ alebo plnšie rozvíja význam pôvodného znaku a je za pôvodný znak dosaditelný, podla ovela skeptickejšieho a podozrievavejšieho J. Derridu často zastupuje, nahrádza, rozširuje, odkladá a niekedy zakrýva pôvodný, starší význam.

Interpretovat’ nejakú semiotickú položku vždy „... znamená „preložit“ ju do inej položky (možno aj celej rozpravy)“ (Eco, 2000, s. 31). Výsledok, interpretant, sa môže stat’ predmetom d’alšieho „prekladu“, interpretácie a tento zase dalšieho. Takto môže teoreticky donekonečna postupovat’ ret’az interpretácií (či re-interpretácií), ktorú Ch. S. Peirce nazval „neobmedzená semióza“, C. Geertz zase „pochopenie pochopenia“ či „interpretácia interpretácie“. S takouto možnostou nekonečného narastania interpretácií okolo interpretovaných znakov, založenou na pozoruhodnej schopnosti znakov navzájom sa zastupovat a nahrádzat', treba počítat aj pri analýze možných starších a mnohonásobnou interpretáciou odložených a zakrytých významových vrstiev slova igric.

Takáto nekonečná, neobmedzená a nezastavitelná semióza spôsobuje podla postštrukturalistických myslitelov, že význam slov je v princípe nestabilný, odložený, nahradený (a tým rozšírený alebo aj zakrytý), teda vyvíjajúci sa a intertextuálny, čo radikálne zdôrazňoval predovšetkým J. Derrida. „Ked' sa napríklad pozrieme na význam slova do slovníka, sme odkázaní na d’alšie slová v nekonečnom procese odkladania, kde význam kľze po retazci označujúcich a ruší trvalé označované" (Barker, 2006, s. 155).

Ak sú nám tieto zistenia radikálnych postštrukturalistických myslitelov typu J. Derridu, zásadne spresňujúce povahu Peircom popísanej nekonečnej semiózy tým, že ukazujú principiálnu nestabilitu významu slov, blízke, musíme predpokladat, že slová sú „klzký nástroj“, význam slov nie je ani jasný ani pevný. Určenie významu slov je v procese označovania neustále odkladané a doplňované. Slová nesú mnoho významov, vrátane ozvien a stôp po význame príbuzných slov v iných kontextoch. Ak hladáme v slovníku význam nejakého slova, odkazuje nás na iné slová „v nekonečnom procese intertextuálneho odkla$d u$ “ (Barker, 2006, s. 14). Preto si dovolíme podozrievavo predpokladat', že v stredoveku obvyklý preklad slovanského slova igric (< ${ }^{\star}$ jьgrьсь) latinským jokulátor nahradil odložil a ukryl jeho starší význam. Náhrady totiž význam slova vždy rozširujú a zastupujú. Význam slova nie je nikdy definitívne fixovaný, skôr je nahradzovaný, (zastupovaný, rozširovaný) „odleskami“ iných slov, včítane ozvien alebo stôp po významoch súvisiacich, teda napr. aj pri preklade používaných slov z iných kontextov, z iných jazykov. Význam je teda 
vždy nezmazatel’ne poznačený interpretáciami, prekladmi, a aj vdaka tomu „klže po retazci označujúcich a narušuje stabilitu označovaného“ (Barker, 2006, s. 196).

Spätný preklad latinského jokulátor archaickým slovanským slovom igric (čo je fosília spätne prevzatá z mad’arčiny, hláska „g“ totiž v slovenčine zanikla a bola nahradená hláskou „h“ už v 13. storočí, „živý“ kontinuant starobylého slova igric je napr. slovenské toponymum Ihráč) po mnohých storočiach preto nepredstavuje automatický návrat, reštitúciu pôvodného významu, slovo igric $\mathrm{v}$ dnešnom (slovenskom) odbornom slovníku môže byt’ bez protestov odbornej verejnosti nahradené slovami figliar, vtipkár, šašo, „žartovník“" (takto napr. prekladal latinské slovo jokulátor slovenský romantický historik Sasinek), ktoré sú korektnými interpretantmi skôr latinského slova jokulátor.

Ak tieto zistenia, zdôrazňujúce principiálnu nestabilitu významu slov, dôsledne aplikujeme na slovo igric, začneme ho vnímat' ako problematickú fosíliu, ktorej význam vel’mi pravdepodobne tiež „kĺzal“ po retazci označujúcich, bol odkladaný a nahrádzaný, aj ked’ prechodne stabilizovaný, fixovaný viacerými konvenciami. Tento proces musel nutne narušit i stabilitu označovaného, jeho výsledkom je súčasná, domnievame sa, že nekorektná predstava igrica - zabávača (jokulátora). Pokúsime sa naznačit jej umelost’ a neadekvátnost’ a navrhnút inú konvenciu, ktorá by fenomén igricov predstavila v inom svetle, pokúsime sa donútit mechanizmus „kĺzania“a zakrývania významu k spätnému chodu.

Stredoveký pokus nahradit’ a následne novou a odlišnou konvenciou fixovat význam slova igric prekladom do neadekvátnej terminológie literárnej latinčiny, robený, nazdávame sa, s polemickým a dehonestujúcim úmyslom, teda odmietneme v mene pokusu o prípadnú reštitúciu dávnejšieho nahradeného a zakrytého významu. Na podobný fenomén neadekvátneho prekladu - zakrytia v nemeckých literárnych dejinách upozorňuje Gesine Lüben, podla ktorej sa ranostredoveké pramene „... zmieňujú o pohanských piesňach, carmina, a spevákoch, poetae, či potulných básnikoch, ioculatores, neadekvátnou terminológiou literárnej latinčiny, spravidla len mimochodom a s polemickým a dehonestujúcim úmyslom“ (Lüben, 1999, s 33)). Aj Jacques Le Goff upozorňuje: „Nesmíme ovšem zapomínat, že prízviskem joculator, kejklír častovali v té době (v 12. storočí - pozn. autora) všechny, kteři byli považováni za nebezpečné a měli být vyloučeni ze společnosti. Joculator, to znamená také buřrič, rebel..." (Le Goff, 1999, s. 37).

Úspešný pokus fixovat nový, nahradený význam slova igric novou konvenciou (jokulátor, teda figliar, vtipkár, šašo) budeme vnímat’ ako doklad vzmáhajúceho sa mocenského vplyvu cirkvi. Tej sa postupnou reguláciou významu, dosahovanou procesom kultúrnej habituácie (teda tým, že si spoločenstvo postupne navykalo na nové konvencie, ktoré sa potom začali javit’ ako prirodzené a jedine možné) darilo zakrývat’ svoje mocenské praktiky. Akt nahradenia, odloženia, zakrytia starého významu a postupnej naturalizácie nového významu (tento nový význam môže byt aj dnes vnímaný bezproblémovo ako prirodzený, samozrejmý a večný, úplný a dokončený) budeme vnímat ako účinný prostriedok boja s pohanstvom a jeho predstavitelmi. Pod týmto "prirodzeným a večným“ významom môže byt’ ukrytá dnes už „neprirodzená“ a „nesamozrejmá“ časovo ohraničená minulá konvencia (spájajúca toto označujúce s iným označovaným). Kĺzanie významu slova igric sa pokúsime predstavit ako vzorový prípad nahrádzania a odkladania, niekedy zámerného zakrývania významu. 


\section{Etymológia praslovanského slova ^jøgrıcь ako možnost’ uniknút neadekvátnej terminológii literárnej latinčiny}

Niektoré stredoveké pramene ukazujú spojitost' hudobnej produkcie a pohrebov u starých Slovanov, čo môže ukazovat na archaickú prvofunkčnú kompetenciu riadenia pohrebných obradov a hostín, ktoré volakedy vykonávali igrici (kým ich cirkev v tejto sfére tolerovala). Arabský geograf Gardízí (zomrel v r. 1039) o Slovanoch píše: „Majú rozličné hudobné nástroje, ako lutny, bubny a píštaly; ich píštala je 2 lakte dlhá a ich lutna má 8 strún. Nápoje sa zhotovujú z medu. Pri spalovaní mŕtveho hrajú na takýchto nástrojoch domnievajúc sa, že sa majú tešit, že Pán ho (nebohého) prijal do svojej milosti “ (Pramene $\mathrm{k}$ dejinám Velkej Moravy, 1964, s. 329).

Túto stopu, ukazujúcu na spojenie archaického slovanského „básnika“, igrica, s podsvetím, so svetom mŕtvych, ale i s využitím psychoaktívnych látok počas pohrebných rituálov sa pokúsime podporit ešte jedným etymologickým argumentom, pokúsime sa teda pravdepodobne nekorektne fixovaný význam slova „rozhýbat“ aj etymologickými prostriedkami Starý slovanský termín ^jbgrbcb má totiž u všetkých Slovanov svoje kontinuanty (bulharské igréc, srbochorvátske igrc, igarac, slovinské igrc, igrèc, staročeské jhřec, hřec, slovenské herec, lužické gerc, staropol’ské igrzec, staroruské igrbcb, igréc (Trubačev, 1981, s. 208-213)). Slovo igric pekne zakonzervovala aj mad’arčina, ktorá ho prevzala ${ }^{1}$. V súčasnej slovenčine (po zmene $g>h$, ktorú jazykovedci datujú do 13. storočia) má slovo igric viacerých „potomkov“ - napr. herec, hráč, ihrisko.

Etymológia slova ${ }^{\star} j$ ggrbcb smeruje k praslovanskému *jogra, ktoré považuje Rejzek (2001, s. 212) za starý rituálny termín: staroruské „igry“ boli pohanské rituálne tance so spevmi. Velmi podrobne o viacerých pokusoch osvetlit’ etymológiu slova *jogra informuje Etimologičeskij slovar slavjanskich jazykov (Trubačev, 1981, s. 208-213). Najstarším sémantickým obsahom slova *jogra bol pravdepodobne archaický komplex významov označujúci „spev s tancom“. Autor hesla uvažuje o spätosti významu tohto slova so svetom pohanských sakrálnych predstáv, dejov a výrazov a rozvíja d’alej názor A. A. Potebňu, publikovaný ešte v roku 1881, predpokladajúci, že toto slovo patrí k pohanskej sakrálnej sfére. Potebňa sa domnieval, že - $r$ - v slove ${ }^{\star} j$ ggra je sufix a nie čast’ koreňa. Následne, po tejto operácii, kedy sa zbavil problémového -r-, sa ako prvý snažil zblížit toto slovo ety-

\footnotetext{
1 Významné stopy po prvofunkčných náboženských kompetenciách a niektoré dávnejšie korene uhorskej inštitúcie igricov obnažuje madarský historik L. Szegfü (Kristó, 1995, s. 573-574). Hladá ich v madarskom pohanstve, konkrétne v osobe madarského „táltoša“ - šamana, prostredníctvom ktorého ako média v stave extázy rozprával svoj príbeh duch konkrétneho hrdinu v prvej osobe. Z táltoša ako média sa vyvinul regös - igricz, obidva termíny boli v madarčine synonymné (ukazujú to, čo predpokladá v stredovekom Uhorsku J. Steinhübel, a to slovansko-mad’arskú dvojjazyčnost', tento erudovaný slovenský historik o arpádovskom Uhorsku napr. píše ako a o mad’arsko-slovanskom štáte (Steinhübel, 2004, s.301)). Regöši - igrici boli nositelmi pohanstva a hrali dôležitú úlohu v pohanských vzburách, nikdy sa neodtrhli celkom od pohanských tradícií. Ich čast’ sa neprispôsobila novým podmienkam krestanskej spoločnosti a bola tvrdo prenasledovaná, druhá, prispôsobivejšia čast̉ našla svoju realizáciu v oklieštenom priestore, stala sa „jokulátormi“, zabávačmi, predvádzajúcimi svoje umenie na velkých panských pitkách a orgiách. Sprevádzala svojich pánov pri cestách a bojových taženiach, aby hned’ na mieste činu mohla ospievat' ich hrdinstvá. V 16. storočí už slovo „regös (igricz, ioculator)“ malo podla Szekfüa pejoratívny význam. Domnieva, že jazyk ich spevu mohol byt aj mad’arský. K týmto zisteniam možno dodat', že inštitúcia igricov sa teda zrejme nevyvinula len zo staromad’arských táltošov - šamanov; už variantné madarsko-slovanské pomenovanie regös - igricz, dokazuje, že bola i pokračovaním slovanskej, pravdepodobne ešte predvel'komoravskej inštitúcie, že tu ide o evidentný kultúrny synkretizmus.
} 


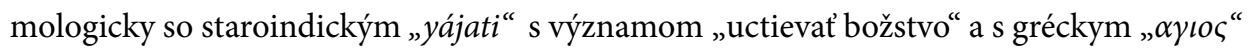
s významom posvätný.

Slovník sa zmieňuje aj o pokuse falzifikovat staršiu, ale dodnes prijímanú Potebňovu etymológiu a upozorňuje, že vzhladom na d’alší fonetický vývin indoeurópskeho palatálneho $\hat{g}>z$ u Iráncov (avestské slovo yazatē) a Slovanov by malo podla niektorých bádatelov vyjst' slovanské *jbzra prípadne *jbzdra, treba teda uvažovat aj o iných etymonoch, na jeden zvlášt nádejný etymon sa pokúsime nižšie upozornit'.

V češtine sa uchovalo formálne podozrivo podobné slovo, ktoré sa mohlo vybrat’ na svoju pút a postupne sa významovo dost’ vzdialit’ od svojich príbuzných z rovnakého slovotvorného hniezda. Je to české slovo „hrana“, „hrany“ a znamená „vyzváňanie za mŕtveho“. Jeho príbuznými sú hornolužické „grono“ - porekadlo, reč, povest', staroslovienske "granz “ - verš a cirkevnoslovanské „granz “, „grajb“ - cirkevný chválospev. Podla Machka (1997, s. 183) ide o málo jasné slovo, ktorým sa azda mienili pôvodne pohrebné veršované spevy. Podla Rejzka (2001, s. 213) praslovanské * gornz je asi starý rituálny termín, súvisiaci z litovským "gírti“ - chválit, oslavovat, starohornonemeckým "queran“ - vzdychat, staroindickým „grnati“ - vzýva, chváli, spieva a asi i latinským „grates“, „gratias“ - dakujem. Všetky môžu pochádzat’ z indoeurópskeho ${ }^{*}$ guer - chválit', velebit'. Holub (1952, s. 132) z tohto koreňa odvodzuje aj staroindické „gurtis“ - chvála, adjektívum "gurtas“ - vítaný i latinské „gratulari“ - blahopriat', sekundárne „Grácie“ - bohyne pôvabu. $\mathrm{Z}$ toho istého indoeurópskeho koreňa odvodzuje Rejzek i Holub aj dalšie praslovanské evidentne náboženské termíny - napr. knižné slovo „žertva“ od praslovanského *žerti slávit, obetovat bohom; z toho odvodené slovo „žrec“ - pohanský kňaz (sláviaci, obetujúci bohom). Kontinuantom starého $g \mathrm{v}$ slovách „žertva“, „„ „̌̌erti “je špecificky slovanská hláska $\check{z}$, ktorá vznikla tzv. prvou palatalizáciou, teda pravidelnou zmenou $g>\check{z}$, ktorá prebehla vo všetkých súčasných slovanských jazykoch v slovách pred samohláskami $e, \check{e}, i, b-\mathrm{a}$ je zodpovedná za vznik špecifických slovanských hlások $(\check{z}, \check{c}, \check{s}<g, k, c h)$, ktoré nepoznal praindoeurópsky jazyk (Petr, 1984). Napríklad ak predpokladáme, že dvojica staropol'ské „igrzec“ a „żyrzec“ („ofiarnik“ (Gieysztor, 1986, s. 35), obetujúci) vznikla z toho istého koreňa * guer, staré $g$ sa mohlo uchovat’ len vtedy, ak sa pôvodne za ním nasledujúca predná samohláska „prešmykla“ a predsunula, čo sa mohlo stat napr. z tabuových dôvodov (kedže zbytočné používanie posvätných názvov pôsobí znevažujúcim dojmom, pôvodné indoeurópske slovo mohlo prejst' rôznymi tabuovo motivovanými obmenami, prestavbami, takýmto zmenám zvlášt často podliehajú práve slová súvisiace so sférou sakrálneho). Ak možno predpokladat takýto vývoj, môže byt' zaujímavé vzájomnú podobnost' slov igric, hrana či žrec využit a pokúsit sa nájst’ spoločné indoeurópske východisko.

Ked’ boli pohrebné žalospevy vytlačené zvonením, bolo slovo hrana „chápané možno ako zvon - stopa tohto významového vývoja je v prevzatom madiarskom slove "harang“ - zvon“, ktoré sa spätným prevzatím podla Machka (1997, s. 516) „vrátilo“ domov v podobe rolnička (z východu pochádzajúci zvonček, pripevňovaný na nohy polovníckych sokolov, prostredníctvom Mad’arov sa dostal ako novinka na západ), po „návrate“ prešlo slovo zmenami harang - haranglička (zdrobňovacia prípona) - skrátenie o (ha) ranglička - rolnička."

Inú významovú dimenziu toho istého koreňa, $\mathrm{z}$ ktorého je odvodené české slovo hrana a mad’arské harang, ukazuje aj slovenská odvodenina „uhranút“ („uhrančivý, napr. v slovnom spojení „uhrančivé oči“) - pôvodne znamenajúca urieknut', zariekaním spôsobit’ niekomu škodu. 
K výpočtu etymologicky „podozrivých“ slov, ktoré, ak pochádzajú z jedného koreňa, môžu osvetlit staršie a zabudnuté významové dimenzie slova igric, možno ešte pridat’ archaické slovo žehrat’ - zo staročeského „žehrati“ - napomínat', kárat', žiarlit’, vyjadrovat’ nespokojnost'. Podla Rejzka etymologicky „nie príliš jasné“ (2001, s. 746), ponúka sa spojenie so slovami „žhnout“, „žárlit“ (v pôvodnom neposunutom význame pálit’ ohňom). Ak budeme vychádzat' z našej hypotézy, potom „žehrat" by mohlo ako zloženina doslova znamenat” „pálit slovom, veršom“, mohol by sa v ňom ukrývat napr. názov zaniknutého staršieho synkretického (slovno-hudobno-rituálno-magického) žánru, ktorého cielom mohla byt napr. zmena správania vysoko postavených osôb, prípadne ich potrestanie (privodit im magicky chorobu a smrt'). Žáner sa už nemohol objavit’ v repertoári stredovekých „jokulátorov“, pretože na cirkevnú kliatbu mala už monopol cirkev. Iným, miernejším obsahom „žehrania“ mohla byt' „páliaca“ satira ako výchovný prostriedok, ktorej názov mohol byt’ odvodený podobnou metaforickou logikou ako názov „páliacej“ žihlavy, „páliaceho“ žihadla.

Nazdávame sa, že by mohlo byt perspektívne hladat etymon slova ${ }_{j b g r b c b}$ na rovnakom mieste, ako etymon slov „žehrat", „hrana“, „uhranút“, „žrec“ a „žertva“. Aby sme to mohli urobit', je nutné spochybnit’ staršiu hypotézu Potebňu, a -r- v slove `jøgra, vnímat' nie ako sufix, ale ako súčast' starého koreňa. Následne by bolo možné uvažovat' o indoeurópskom koreni ${ }^{\star}$ guer - chválit', velebit. Ak etymologické úvahy presmerujeme $\mathrm{k}$ tomuto koreňu, igric prestane byt’ „umelcom - zabávačom“ a odhalia sa nám možné významové dimenzie prekvapujúco totožné s tým, čo zistuje Toporov o archaických básnikoch a zároveň žrecoch. $Z$ akého indoeurópskeho koreňa je odvodený názov tejto inštitúcie nemôže byt’ lahostajné ani v rámci toho, čo nazývame archeológia literárnej komunikácie (Golema, 2006), môže to totiž osvetlit práve tie dimenzie významu, ktoré boli nahradené a odložené. Ak predpokladáme, že slová igric $\left(<{ }^{*} j b g r b c b\right)$ a žrec $\left({ }^{*} z ̌ b r b c b<{ }^{*} g b r b c b\right)$ sú derivátmi z toho istého koreňa, otvoria sa dimenzie významu, ukazujúce k výkonu prvej funkcie indoeurópskej náboženskej suverenity, nie k predajnému zábavnému figliarstvu, vtipkárstvu, založenému na formálnej dokonalosti a ozdobnosti výpovede, nemajúcemu vztah ku sfére posvätného, poskytujúcemu teda iba to, čo dnes zvykneme nazývat estetické zážitky.

Dnešné významové dimenzie slovenského slova „hra“ (< ${ }^{\star}$ jogra) spájajú túto činnost' predovšetkým s detmi (nevážna, zábave a kráteniu času slúžiaca činnost'), s hudobnými nástrojmi, s divadlom a filmom (herci), športom (ihrisko). Významové metaforické i metonymické posuny, rozšírenia, zúženia i nahradenia významu, ktoré určovali kariéru tohto pôvodne starého rituálneho termínu, idú jedným smerom, a tým je zneváženie, vytlačenie dávnej náboženskej terminológie i praxe. Prvofunkčný kredit si ale, podla všetkého, zachovali niektoré archaické odvodeniny i zaniknuté tvary pôvodne azda $z$ totožného indoeurópskeho koreňa ${ }^{\star}$ guer-. Vhodným príkladom by mohlo byt české slovo „hrana“ - vyzváňanie za mŕtveho, v mad’arčine zakonzevovaný tvar „harang“ - zvon, staroslovienske „granz “ - verš (dnešný názov verša je prevzatý z latinčiny - „versus“, sprostredkovaný nemčinou - „Vers“, vytesnenie domáceho slova prevzatým výstižne indikuje osud predkrestanskej slovesnosti, spojenie so svetom mŕtvych v madarskom harang je tiež významná indícia na archaické kompetencie básnikov a žrecov). Ďalšie geneticky pravdepodobne príbuzné slová tiež ukazujú na spojenie so sférou slovesnosti, na uchovávanie textov náboženského obsahu, využívajúce rytmus a hudobný sprievod - dolnolužické "grono“ - porekadlo, reč, povest', hornolužické „,hrono“ - veta, pauza, tep, litovské „gírti“ - chválit', oslavovat'. 
Pragmatiku, použitie, teda magickú „moc“ takto uchovávaných náboženských formúl možno indikuje slovo „uhranút“ - urieknut, zariekavaním, spôsobit niekomu škodu, možno i staročeské „žehrati“ - napomínat', kárat', vyjadrovat’ nespokojnost', „pálit" slovami (túto funkciu možno prevzala krestanská kázeň ako prvofunkčný náboženský žáner).

Ak na základe týchto zistení chceme nájst’ vhodný, významovo ekvivalentný, teda nie posunutý interpretant slova igric, ktorý by bol použitelný pri úsilí o zhustený, emický popis v stredovekých prameňoch len „zriedene“ a „eticky“ popísanej predkrestanskej (či polokrestanskej) kultúry stredovekých Slovanov, musíme odmietnut termín jokulátor a jeho súčasné synonymá (šašo, vtipkár, figliar, zabávač). Ten už totiž velmi pravdepodobne odráža neúctu, ktorá dopadla na osoby igricov a ich povolanie po dokonanej christianizácii niekedy na konci 12. storočia. Pri hladaní presnejších významových ekvivalentov siahneme mimo rámca našej krestanstvom sformovanej kultúry a slovnej zásoby. Podobne motivované, s rituálnym používaním slova spojené je staroveké indické slovo „brahman“ (pôvodný význam bol približne „účinná slovná konštrukcia, formula, modlitba“, teda sémanticky podobný ako staroslovienske "granz" - verš a cirkevnoslovanské "granz"a "grajb“ - cirkevný chválospev), ktoré označovalo celú kastu pamätových špecialistov v rámci jazykového systému, $\mathrm{v}$ ktorom hodnotu slov ešte monopolne určovala trojfunkčná indoeurópska ideológia. Kosmovi „starci“ (ktorých bájny „prednes“ podla Karbusického Kosmas skrátil a transformoval vo svojej kronike) konzervujúci staršie štádiá epiky a príliš spojení so starou kmeňovou kultúrou, mohli teda reprezentovat ešte tú vetvu igricov, ktorá sa funkčne dá skôr pripodobnit k indickým brahmanom ako k stredovekým „zabávačom" - jokulátorom.

Takýto typ pamätových špecialistov možno predpokladat nielen $\mathrm{v}$ přemyslovskom, ale i v arpádovskom a v piastovskom stredovekom štáte, a tak isto v štátnom útvare, ktorého následníkmi tieto štáty boli, teda na Vel'kej Morave. Korene inštitúcie igricov mohli siahat' ešte hlbšie, k menším slovanským kniežatstvám vznikajúcim v stredoeurópskom priestore už od slovanskej expanzie v 6. storočí, ba ešte hlbšie, k Praslovanom, svojsky adaptujúcim a zároveň uchovávajúcim staré indoeurópske pamätové inštitúcie a mytologické príbehy.

\section{Literatúra}

Assmannová, A. - Assmann, J.: Archeológia literárnej komunikácie. In: Úvod do literární vědy. Usporiadali Miltos Pechlivanos, Stefan Rieger, Wolfgang struck a Michael Weitz. Praha : Herrmann \& synové, 1999, s. 200-206.

Assmann, J.: Kultura a pamět. Praha: Prostor, 2001.

Barker, Ch.: Slovník kulturálních studií. Praha: Portál, 2006.

Botheroydová, S. - Botheroyd, P.: Lexikon keltské mytologie. Praha: Ivo Železný, 1998.

Buczynska - Garewicz, H.: Semiotika a dekonštrukcia. In: Estetika, roč. XXXVI., 2000, č. 1, s. 52-60.

Canfora, L.: Dějiny řecké literatury. Praha: KLP, 2001.

Curtius, E. R.: Evropská literatura a latinský středověk. Praha: Triáda, 1998.

Dumézil, G.: Mýty a bohové Indoevropanů. Praha: OIKOYMENH, 1997.

Dumézil, G.: Mýtus a epos I. Trojfunkční ideologie v eposech indoevropských národů. Praha: OIKOYMENH, 2001. 
Eliade, M.: Dejiny náboženských predstáv a ideí / III. Bratislava: Agora, 1997.

Eco, U.: Mysl a smysl. Sémiotický pohled na svět. Praha: Vize 97, 2000.

Geertz, C.: Interpretace kultur. Praha: Sociologické nakladateství, 2000.

Gieysztor, A.: Mitologia Slowian. Warszawa: Wydawnictwa Artystyczne i Filmowe, 1986.

Golema, M.: Stredoveká literatúra a indoeurópske mytologické dedičstvo. Prítomnost’ trojfunkčnej indoeurópskej ideológie v literatúre, mytológii a folklóre stredovekých Slovanov. Banská Bystrica: Pedagogická fakulta Univerzity Mateja Bela, 2006.

Herm, G.: Kelti. Bratislava: Obzor, 1985.

Herodotos: Dejiny. Bratislava: Tatran, 1985.

Holub, J.: Etymologický slovník jazyka českého. Praha: Státní nakladatelství učebnic, 1952.

Ivanov, V. V. - Toporov, V. N.: Slavjanskije jazykovyje modelirujuščie semiotičeskije sistemy. Moskva: Nauka, 1965.

Jančovič, I.: Interpretácia: medzi textom a „svetom“. In: Minulé a súčasné podoby filozofickej reflexie človeka. Banská Bystrica: FHV UMB, 2006, s. 61-66.

Jančovič, I.: Tematizácia outsiderstva v prozaickom texte a možnosti jej literárnovedného výskumu. In: Človek z okraja uprostred literatúry. Banská Bystrica: Fakulta humanitných vied Univerzity Mateja Bela, 2007, s. 7-57.

Jakobson, R.: The slavic god Veles and his Indo-European cognates. In: Studi lingvistici in onore di Vittore Pisani, Torino, 1969, s. 579-599.

Kanovský, M.: Kultúrna a sociálna antropológia. Bratislava: CHRONOS, 2004.

Karbusický, V.: Báje, mýty, dějiny. Nejstarší české pověsti v kontextu evropské kultury. Praha: Mladá fronta, 1995.

Kosmova Kronika česká. Praha: Svoboda, 1975.

Kováč, L.: Veda v optike kognitívnej biológie. In: Tvorba Roč. IV, č. 8, 1994, s. 7-9.

Kováčik, L.: Mytologizmus v slovenskom literárnom romantizme. Banská Bystrica: Univerzita Mateja Bela, Pedagogická fakulta, 2003.

Kožiak, R.: Írski misionári a počiatky krestanstva u Slovanov v stredovýchodnej Európe. In: Pohanstvo a krestanstvo. Zostavili R. Kožiak a J. Nemeš. Bratislava: Chronos, 2004, 103-124.

Kožiak, R.: Špecifické črty vývoja krestanstva a monasticizmu v Írsku v ranom stredoveku. In: Rehole a kláštory. Zostavili Rastislav Kožiak a Vincent Múcska. Bratislava: Chronos, 2002, s. 31-48.

Krajčovič, R.: Živé kroniky slovenských dejín skryté v názvoch obcí a miest. Bratislava: Literárne informačné centrum, 2005.

Kristó, G. et al: Korai magyar történeti lexikon (9-14. század) föszerk. Budapest: Akadémiai kiadó, 1994.

Kronika anonymného notára krála Bela Gesta hungarorum. Preložil, poznámkami a registrom opatril, úvodnú štúdiu napísal Vincent Múcska. Budmerice: Rak, 2000.

Krško, J.: Hydronymia povodia Hrona. Banská Bystrica: Fakulta humanitných vied UMB, 2008.

Krzemieńska, B. - Třeštík, D.: Hospodářské základy raně středověkého státu ve střední Evropě (Čechy, Polsko, Uhry v 10.-11. století). In: Československý časopis historický, roč. XXVII, 1979, č. 1, s. 113-130.

Le Goff, J.: Intelektuálové ve stř̌edověku. Praha: Univerzita Karlova v Praze, nakladatelství Karolinum, 1999. 
Lotman, J.: Text a kultúra. Bratislava: Archa, 1994.

Lüben, G.: Orální slovesnost - psaná literatura. In: Úvod do literární vědy. Usporiadali Miltos Pechlivanos, Stefan Rieger, Wolfgang Struck a Michael Weitz. Praha: Herrmann \& synové, 1999, s. 32-36.

Machek, V.: Etymologický slovník jazyka českého. Praha: NLN, 1997.

Merhautová, A. - Třeštík, D.: Románské umění v Čechách a na Moravě. Praha: Odeon, 1983.

Mify narodov mira. Enciklopedija v dvuch tomach. Moskva: Sovetskaja enciklopedija, 1988.

Múcska, V.: Boj uhorského štátu proti pohanstvu v 11. storočí. In: Pohanstvo a krestanstvo. Zostavili R. Kožiak a J. Nemeš. Bratislava: Chronos, 2004, s. 201-210.

Niederle, L.: Rukovět slovanských starožitností. Praha: Nakladatelství Československé akademie věd, 1953.

Peirce, CH. S.: Logika ako semiotika: teória znakov. In: Pragmatizmus. Malá antológia filozofie 20. storočia. Bratislava: IRIS. 1998, s. 131-141.

Petr, J.: Základy slavistiky. Praha: SPN, 1984.

Pleterski, A.: Strukture tridelne ideologije v prostoru pri Slovanih. In: Zgodovinski časopis, roč. 50, 1996, č. 2, s. 163-185.

Pramene k dejinám Velkej Moravy. Na vydanie pripravil Peter Ratkoš. Bratislava: Vydavatel'stvo slovenskej akadémie vied, 1964

Puhvel, J.: Srovnávací mythologie. Praha: NLN, 1997.

Rejzek, J.: Český etymologický slovník. Voznice: LEDA, 2001.

Rybaryč, R.: Dejiny hudobnej kultúry na Slovensku I. Bratislava: OPUS, 1984.

Slovo o pluku Igorovom. Preložila Helena Križanová-Brindzová. Bratislava: Mladé letá, 1986.

Steinhübel, J.: Nitrianske kniežatstvo. Bratislava: Veda, 2004.

Struck, W.: Sociální funkce a kulturní statut literárních textů neboli: Autonomie jako heteronomie. In: Úvod do literární vědy. Usporiadali Miltos Pechlivanos, Stefan Rieger, Wolfgang struck a Michael Weitz.Praha: Herrmann \& synové, 1999, s. 184-200.

Třeštík, D.: Kosmas. Praha: Svobodné slovo, 1966.

Trubačev, O. N. et al.: Etimologičeskij slovar slavjanskich jazykov 8. Moskva: Nauka, 1981.

Turner, V.: Průběh rituálu. Struktura a antistruktura. Brno: Computer Press, 2004.

Váňa, Z.: Svět slovanských bohů a démonů. Praha: Panorama, 1990. 
Actors (Igrci) as Archaic Poets and Sacerdotal Priests among the Pagan Slavs.

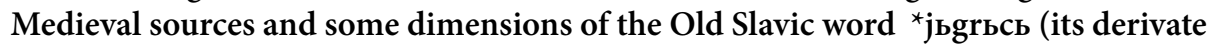
and continuity) as followed in significant Slavic ethnolinguistic traditions

\section{Martin Golema}

The study gives a sketch of a Slavic memory specialist, an archaic pagan poet, whose functional competence in the Middle Ages has been accepted by the church. The study formulates the answer to the question "Who were medieval Slavic actors („igric“), and what place did they occupy in the conceptual framework (secondary modeling system) of a three-functional ideology?” The theme of actors (,igric“) is represented as one of the central and perspective topics which can also be surveyed by the archeology of literary communication, studying the history of the text before a literary epoch. 